\title{
Samuel Johnson's view about Oduduwa in connection with the origins of the Yoruba
}

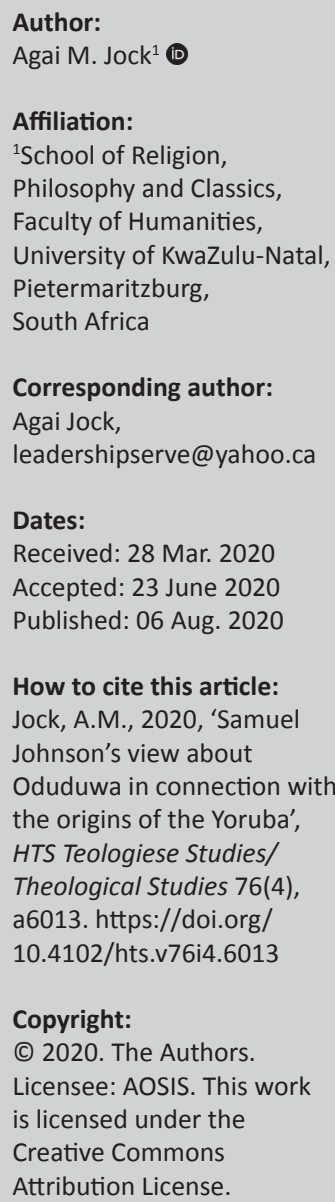

The most favourable explanation pertaining to the Yoruba origin is that of the Oduduwa tradition according to which he is the original ancestor of the Yoruba people. Although the Yorubas have reached a settlement on Oduduwa as their ancestor, they disagree on the origin of Oduduwa. Whilst some associated his origin with Mecca or Arabia, others say Egypt or Israel. Samuel Johnson, the most prominent writer of the Yoruba history, discussed various theories that pertained to the origin of Oduduwa. He argued that Oduduwa or the original ancestors of the Yoruba people were Coptic Christians. Writers of Yoruba history from the 20th and 21st centuries had continued to build upon Johnson's view of the Yoruba origin in connection with Oduduwa. This research is a study of the Yoruba and Johnson's perspectives of Oduduwa in connection with the Yoruba origins. The research elucidates the circumstances of Johnson's Christianisation of the Egyptian origin of the Yoruba.

Contribution: This article shall contribute to a distinct understanding of the origin of the Yoruba in connection with the identity and the personality of Oduduwa. Students of history and cultural studies will find this research of utmost benefit because it explains the origin of the Yoruba from the perspective of Samuel Johnson, the first Yoruba man to document extensively on the Yoruba history, language, its culture and its people in a single document or collection.

Keywords: Africa; ancestor; Ancient Near East; Ile-Ife; migrant legend; myth; Oduduwa; oral tradition; Yorubaland.

\section{The Yoruba people of Nigeria}

Various ethnic groups around the world, and particularly in Africa, are finding it necessary to establish a clearer history pertaining to their origins. Whilst some ethnic groups use the history of their origins to reaffirm their unity, others find solace in defining their identities through the history of their origins. There are other people in different parts of the world who believe that their ancestral roots could be traced to Africa like some African Americans. Moreover, a number of Africans in the Caribbean have sponsored research studies that could give them knowledge regarding their origins in connection with Africa. Some of the most popular ethnic groups that some Africans in diaspora associated their origins with are the Hausas, the Igbos, the Yorubas, the Mande, the Akan and many more (Agai 2018:86). The Yoruba people in particular are found in various parts of the world including Nigeria, Togo and Benin Republic (Ade 2006:xiii). There is also a connection with the practices of their religions that are similar to some of the religious practices found in Bahia, Brazil, Cuba, Dominican Republic, Guyana, Haiti, Jamaica, Puerto Rico, Suriname, Trinidad and Tobago, Uruguay, Argentina, Venezuela and many more. ${ }^{1}$ The Yoruba culture is likely spread in many parts of the world which suggest that the Yoruba people can be described as a people that find it difficult to forfeit their culture whenever they find themselves. On this subject, Ade quoted Awolalu:

... no African group has had greater influence on the culture of the New World than the Yoruba. Today, their descendants still preserve Yoruba culture and traditions in parts of the Caribbean and South America, particularly in Cuba and in Brazil as well as in North America. In many parts of the Caribbean and South America, for example, Yoruba Religion has been accommodated to Christianity; Yoruba divinities have been identified with Catholic saints. (Ade 2006:xiii)

This research is not aimed at ascertaining whether the Yoruba people influenced those in the Caribbean and the Americas. Although the researcher appreciates the interest in the comparative

1.The Yoruba people, for example, believe in the religious concept of Orisha according to which one deity has to be worshipped and the deity has to possess one of the manifestations or features of God. This view is also common in the religions of ethnic groups in the Caribbean and the Americas. 
studies between the cultures of the Yorubas in Africa and the cultures of some ethnic groups in the Caribbean and the Americas done by many scholars, this research concentrates on the study of the Oduduwa oral tradition in connection with the Yoruba origins from the perspective of Samuel Johnson and other Yorubas (cf. Ayandele 2004:121). The research is centred around the Yoruba people of Nigeria. The Yoruba people of Nigeria occupy the south-western region of the most populous West African country comprising six geographical states: Oyo, Osun, Ondo, Ogun, Lagos and Ekiti. The Yorubas are also found to be indigenes of Kogi and Kwara states of North-Central Nigeria. The Yoruba people formed one of the largest ethnic groups in Africa with a population of over 40 million living in Nigeria alone (cf. Ayandele 2004:121). Despite their high population size and other achievements, the writing of the history of their origin is still in contention (Afolayan 2004:32; Johnson 1921:3)

There are various theories regarding the origin of the Yoruba. Whilst some conclude that the Yoruba people originated from Mecca or Arabia, others claim that the Yoruba people came from Egypt or Israel (Agai 2013:1; Oyebade 2004:53-54). Samuel Johnson was among those who proposed that the Yoruba people originated from Egypt. According to him, Oduduwa was the original ancestor of the Yoruba race because Yoruba oral traditions teach that the Yorubas originated from Oduduwa (Johnson 1921:15). Johnson worked directly with the family members of the kings of Oyo who were responsible for preserving the Yoruba oral history. He said '[ $i] \mathrm{t}$ is on them we depend as far as possible for any reliable information we now possess' (Johnson 1921:3). Whilst the Oduduwa oral tradition proposes a view according to which Oduduwa originated from 'East' or 'Mecca', Johnson disputed this view and associated Oduduwa with the Coptic Christians. He seemed to point out that the Yoruba ancestors were actually of Christian lineage and not Islamic lineage. This research examines the Yoruba conception of Oduduwa with specific interest on how Samuel Johnson interpreted the Oduduwa oral tradition in connection with Yoruba origin.

\section{Samuel Johnson and the writing of The History of the Yorubas}

Samuel Johnson was the renowned writer of Yoruba history. He was born in 1846 to Henry and Sarah Johnson, both of whom were recaptive slaves that lived in Sierra Leone. After the abolition of the slave trade in 1807 , some of the slaves were returned to Freetown in Sierra Leone and were referred to as $A k u$, including the parents of Samuel Johnson (Stevens 2005:1-2). Sarah and Henry returned to their country Nigeria in the 1940s and started to work with the Church Missionary Society (CMS) at the request of Rev. David Hinderer who served the CMS in Abeokuta and Ibadan. The relocation of his parents to Nigeria introduced him to the Christian mission (Falola 1999:33-34). Samuel Johnson did his professional academic study at the Abeokuta Training
Institution between 1863 and 1865. It was at this institution that he studied general education, Greek, Latin, English language, religious studies, philosophy, history and mathematics at the advice of David Hinderer and Gotlieb Buhler (the principal of the institution) (Olabimtan 2011:1-6).

After his graduation in 1865, he served as a teacher at Anglican mission centres in Ibadan, Aremu and Kudi. As a major requirement to becoming a full-time missionary, Samuel Johnson served as an assistant to Deacon Daniel Olubi in 1867 and became a catechist in 1875 at the Aremu Church (Falola 1999:32). He also served as a translator between the Yoruba chiefs and the foreign administrators who colonised Nigeria before its political independence in 1960 and between Christian missionaries and the Yoruba people in general. He mediated between various Yoruba groups and British leaders that served in Nigeria for 17 years during the Yoruba conflicts of the early 19th century (Falola 1999:31, 35-36; Omolewa 2008:124-133). He hated the Yoruba wars and might have been motivated to write The History of the Yorubas in order to unite the Yoruba people. Doortmont (1991) said '[t]ime and again he took the opportunity to tell the people [and his superiors in Lagos and London] that war was evil, producing only hardship and scarcity' (p. 171). Johnson's exposure to various Yoruba leaders and ordinary citizens, likewise his experiences of the Yoruba wars, his mediation work and his interest to know the Yoruba people better, gave him an edge in the knowledge and the writing of the history of the Yoruba people (Falola 1999:32).

After his experiences of mediation with the Yoruba people, Johnson saw that nothing or not much was written about Yoruba history during his time. He saw a need to write to the future generations about what transpired with the Yoruba people in his time. He was worried that the educated Yoruba people knew so much about the history of England, Rome and Greece but not their own history (Johnson 1921:viii). He noted that his main objective for writing The History of the Yorubas was not to be popular in print but as an expression of a form of patriotism towards his people (Johnson 1921):

$[\mathrm{W}]$ hat led to this production was not a burning desire of the author to appear in print - as all who are well acquainted with him will readily admit - but a purely patriotic motive, that the history of our fatherland might not be lost in oblivion, especially as our old sires are fast dying out. (p. viii)

He valued any information or book that pertained to the Yoruba people, culture and history. During his mediation between Yoruba chiefs, the British in Nigeria and the ordinary Yoruba people, he carefully began to document Yoruba history. He received oral information about the Yoruba people and their origins from royal barbs that lived and worked with various Yoruba kings. The royal barbs stored oral information about the Yoruba people (Johnson 1921:viii). He also relied on information from Yoruba notable leaders like David Kukomi (a soldier who participated in some of the wars that took place in Yorubaland), the Venerable Lagunju 
the Timi of Ede (an oral historian), Josiah Oni (an intelligent man who had wide knowledge of the Yoruba people) and many others (Johnson 1921:viii). After completion of the writing of his manuscript The History of the Yorubas in 1897, which took Johnson 20 years to complete, it was sent to England for publication through the CMS in 1897, but it got lost (Olabimtan 2009:118). In 1900, Obadiah travelled to England to inquire about the publication of the book but was told that the manuscript was lost. In 1901, Samuel Johnson died and Obadiah never wanted his late brother's effort of writing the book to go in vain, so he decided to rewrite the manuscript using the diaries of Samuel and other information he received from Samuel before he died: ' ... and it has now fallen to the lot of the editor [Obadiah] to rewrite the whole history anew, from the copious notes and rough copies left behind by the author' (Johnson 1921:ix). The level of changes or influence Obadiah had over the manuscripts is not clear, but he curtailed and amplified certain chapters in the book, which was later published in 1921 by the Church and School Supplies (Johnson 1921:ix).

The book The History of the Yorubas: From the Earliest Times to the Beginning of the British Protectorate was written by Rev. Samuel Johnson and edited by his elder brother Obadiah Johnson, a medical doctor by profession. The book is about 740 pages and, in the book, the author starts by introducing who the Yoruba people were. In fact, the book is divided into two parts. Part 1 discusses the Yoruba people and their culture, and the subchapters include information about the Yoruba language, grammar, origin, towns, villages, tribes, names, manners and customs. Part 2 of the book discusses the Yoruba heroes, gods and mythological kings. Regarding the Yoruba origin, Johnson mentions the origin of the Yoruba that connects them to Oduduwa and dissociates them from Islam (Johnson 1921:5-7). Johnson's book The History of the Yorubas is regarded by the writers of Yoruba history as the most detailed and likely precise document on Yoruba history ever written (Akintoye 2004:3). Other writers who wrote Yoruba history after 1901 had to rely on Johnson's book as a vital document to write Yoruba history (Johnson 1921):

[T] he History of the Yorubas remains the most comprehensive, most authoritative and easily the most ready reference text on the origin, features and spread of the Yoruba people. Since its first appearance in 1921, the volume has always been sought after by scholars who are genuinely interested in getting an authentic account of the phenomenon of the Yoruba race. (p. vii)

Lucas Olumide's argument that the Yoruba people originated from the Predynastic Egyptians might have had some influence from Johnson's work (cf. Lucas 1970: 391). Doortmont (1991) said that Johnson's book is 'one of the best known works ever published on Nigerian history...' (p. 167). Falola noted that despite some chronological errors in Johnson's book, the Yoruba people still regard it as a sacred book. On The History of the Yorubas, Falola (1999) said '[i]t is an article of faith to many of its readers that Johnson is always right' (pp.33-34). This research shall concentrate on Johnson's perspective of the origin of the Yoruba in connection with Oduduwa.

\section{Samuel Johnson's view about Oduduwa}

It is not known when Yoruba history began to be documented, but it was a normal tradition among Africans to preserve their history through oral tradition, myths, folks, rituals, crafts and many more (Oyebade 2004:52).

Although evidence is scanty or non-available, Umoh suggested that the writing of Yoruba history might have started in the early 18th century. He said (Umoh 1971):

$[I] \mathrm{t}$ is only from this date (1700), when the decadence of the Yoruba Kingdom had set in, that the native chronicles can give us any definite knowledge of the Yoruba history. (p. 117)

The earliest record known to have been written about Yoruba history was that documented by Mohamed Belo, the son of Uthman dan Fodio. Uthman dan Fodio was the founder of Islamic jihad in Nigeria. Mohammed Belo was born on 03 November 1781 (Quadri 1986:53). It is not certain whether Umoh's suggestion about the beginning of documenting Yoruba history around the 1700s pertained to Belo. In Belo's book Infaqul-maysur fi ta rich biladit-Takrur or Infaqul-Maysur, probably written around 1812 in Arabic, he associated the Yoruba origin with Iraq or Arabia, popularly known to be a Muslim region (Lange 2011):

[T] he Yoruba were remnants of the Canaanites of the tribe of Nimūd who were expelled from Iraq by Ya`ub b. Qahtān and who fled to the west before they proceeded via Egypt and Ethiopia until they came to Yoruba. (p. 583)

Belo interacted with prominent traders and Islamic preachers that came from the Middle East, North Africa and Mali to Nigeria. He might also have interacted with the Yoruba people that traded with the Hausas and Fulani in Northern Nigeria. It is likely that he received the knowledge of the tradition of the Yoruba origin from them (cf. Omolewa 2008:90-93). In addition, Lange said that there were traders from the Arab world and some Islamic preachers that came to West Africa in the 9th century to propagate their goals of preaching and doing business at the same time. He noted that the Arabs, some of whom were geographers and traders, documented the history of West Africans in the 9th century. Some of the Arabians that wrote the history of the West African people included the Iraqi born al-Ya ${ }^{\varsigma} q u \bar{b} \overline{\mathrm{I}}$, who completed the Ta'rilkh [history book] around $873 \mathrm{AD}$, Ibn Qutayba (in the 9th century) and al-Mas ${ }^{\varsigma} \overline{\mathrm{u}} \overline{\mathrm{I}}$ (who wrote in the 10 th century).

Lange (2011) said that al-Ya $a^{\varsigma} q u \bar{b} \bar{I}$ connected the history of the origin of West African people to the Ancient Near East:

[T] he people of the progeny of Hām, son of Noah, left the country of Babel, went to the west, crossed the Euphrates, continued to Egypt and thence moved to East and West Africa of the Nile the Zaghawa settled in kanem, next the Hausa

2.Originally from Gummi Abu Bakr (ed.), Infäaq-maysür, Cairo: Darwa-matabi al-shab, [WR 1812], p. 48. 
(text: HWDN), then the Kawkaw and finally the people of Ghana. (p. 580)

Falola and Heaton (2010:90-93) said that Arab traders have continued to patronise West Africa from the 11th century through the 18th century. The association of Oduduwa and the Yoruba origin with the 'East' (Johnson 1921:5) in the Yoruba oral tradition could have some connection with the Arab people described as the people of the East. This is just a suggestion that is yet to be proven. Belo and the Arab traders and preachers might not have mentioned Oduduwa in their narration of the origin of the West African people and the Yoruba people in particular but associated it with Iraq, Mecca and Egypt. These regions are significant regions in the history of the Yoruba people. Johnson explained that Mohammed Belo was responsible for associating the Yoruba origin with Iraq, an Islamic country. He said that it was the only written record that pertained to Yoruba history during his time (Johnson 1921):

$[T]$ he only written record we have on this subject is that of the Sultan Belo of Sokoto, the founder of that city, the most learned if not the most powerful of the Fulani sovereigns that ever bore rule in the Soudan. (p. 5)

However, Belo did not mention the statutory role of Oduduwa in the writing of the Yoruba history. Johnson agreed with Belo's view that the Yoruba origin has some connection with Egypt and Arabia or Mecca. He taught that the Yoruba oral tradition regarding Oduduwa's origin is in connection with the 'East', which the Yoruba people thought that the East meant Mecca '[w]ith them the East is Mecca, and Mecca is the East' (Johnson 1921:5). Johnson (1921) further argued that the history of Yoruba origin that connected them with the 'East' can be linked to the history of Mohammed, the founder of Islam:

$[I] \mathrm{t}$ is very curious that in the history of Mahomet we read of a similar flight of his first converts from Mecca to the East Coast of Africa (the first Hegira), ... (p. 6)

However, Johnson argued that the Yoruba concept of 'East' does not mean Mecca, but Egypt. He believed that the Yoruba culture and the Egyptian culture are similar in many ways and that the ancestors of the Yoruba could have been the Egyptians. He said (Johnson 1921):

$[T]$ hat the Yorubas came originally from the East there cannot be the slightest doubt, as their habit, manners and customs, etc., all go to prove ... the Yorubas are certainly not of the Arabian family and could not have come from Mecca universally known in history, and no such accounts as the above are to be found in the records of Arabian writers of any kings of Mecca ... (p. 50)

It is not known whether or not Johnson read about the Arabs and the North Africans that proposed that certain ethnic groups in West Africa such as the Hausas and the people of Ghana originated from the Ancient Near East or Arabia (cf. Lange 2011:580). He said that there is no Arabian record that proposed that the Yoruba people originated from Mecca (cf. Johnson 1921:50). Based on the information that pertained to the origins of West African people from Arabia, there seems to be no specific mention of the Yoruba people as one of the ethnic groups that originated from Arabia by the Arab traders and preachers, except for Belo, who clearly associated the Yoruba origin with Arabia or Mecca or the Ancient Near East (Johnson 1921):

[T] he inhabitants of this province (Yarba) it is supposed originated [sic] from the remnant of the children of Canaan, who were of the tribe of Nimrod. The cause of their establishment in the West of Africa was, as it is stated, in consequence of their being driven by Yar-rooba, son of Kahtan, out of Arabia to the Western Coast between Egypt and Abyssinia. From that spot they advanced into the interior of Africa, till they reached Yarba where they fixed their residence. On their way they left in every place they stopped at, a tribe of their own people. Thus it is supposed that all the tribes of the Soudan who inhabit the mountains are originated from them as also are the inhabitants of Ya-ory. Upon the whole, the people of Yarba are nearly of the same description as those of Noofee (Nupe). (pp. 5-6) ${ }^{3}$

Although the Arabs did not mention the Yoruba among the languages that originated from the Near East to West Africa, in principle they might have anticipated the Yoruba people as well. A weakness about the Arabian view of the origin of the West African people is that it is doubtable that almost all the ethnic groups in West Africa originated from one source in the Ancient Near East. Johnson, however, believed that many ethnic groups in West Africa, such as the Ashanti and the Gas of Ghana, the Fanti people of Ivory Coast and Ghana, the Dahomians of the Benin Republic and the Popos (distributed in many part of West Africa), might have originated from Ile-Ife because they still pay tribute to the paramount Yoruba chief (Johnson 1921:5-6). Johnson preferred to associate the Yoruba origin with the Egyptians and Christianity in particular. He said (Johnson 1921):

[I]t might probably then be shown that the ancestors of the Yorubas, hailing from Upper Egypt, were either Coptic Christians, or at any rate that they had some knowledge of Christianity. If so, it might offer a solution of the problem of how it came about that traditional stories of the creation, the deluge, of Elijah, and other scriptural characters are current amongst them, and indirect stories of our Lord, termed 'son of Moremi'. (p. 7)

There is a myth about the Yoruba god Moremi according to which she sacrificed her only son Olurogbo to the Igbo spirit that tormented Yoruba people of Ile-Ife. The sacrifice was done to liberate the Ife people from constant attacks of the Igbo spirit that tormented the Yoruba people (Johnson 1921:147-148). Johnson thought that the Moremi myth had some connection with the biblical story of Jesus, who was sacrificed for the entire humankind (Johnson 1921:147-148; Jn $3: 16)$. In addition, Johnson thought that the sacred relic called Idi, which Sahibu brought to Yorubaland, was a copy of the Bible and not the Koran, as has been alleged by the Arab tradition of the Yoruba origin (Johnson 1921:6-7; cf. Oyebade 2004:55).

3.S. Johnson, The history of the Yorubas, pp. 5-6, originally from Vide Narrative of Travels and Discoveries, by Major Denham and Captain Clapperton, 1826. Appendix XII, Sec IV. A Tropical Dependency, by Flora L. Shaw (Lady Lugard), 1905, pp. 227-228. 
With regard to Johnson's view on Oduduwa, he narrated the Yoruba myth regarding Oduduwa as he was told by many Yoruba elders, according to which Oduduwa came from the East, Arabia or Mecca or that Oduduwa was a superhuman or a god. However, he disputed any narration that associated Oduduwa with Islam. He thought that Oduduwa or some unknown ancestors of the Yoruba were Egyptians that had some knowledge of Christianity.

There are likely three possibilities that surrounded Johnson's view of Oduduwa: firstly, Oduduwa might be a literal human being that migrated from Egypt to Ile-Ife; secondly, Oduduwa might be a superhuman who had the abilities to create; and thirdly, Oduduwa might be a name of someone the Yorubas did not know, who liberated the Yoruba people. Johnson might have downplayed the view of Oduduwa as a god that was created because of his faith in Christianity, which ascribes creation to the biblical God only. The perception of Oduduwa as a mythical personage by Johnson suggests that Oduduwa might be a real human being or that Oduduwa might just be a name the Yorubas associated themselves with. Johnson (1921) said 'ODUDUWA the reputed founder and ancestor of the race is really a mythical personage' (p. 143), and he noted that other ethnic groups find pleasure in associating their origin with a mythical hero so for the Yorubas ' $[s]$ uch is the desire of most nations to find a mythical origin for themselves through their kings and ancestors' (Johnson 1921:143). ${ }^{4}$ After documenting the Oduduwa tradition, as narrated by the Yoruba people he interviewed, Johnson said that the story might be authentic or mythological '[ $f$ ]rom the statements and traditions, whether authentic or mythologic ...' (Johnson 1921:6). These suggest that Johnson's connection of the Yoruba origin with Christianity or Christians is paramount to just a single individual by the name Oduduwa.

\section{The Yoruba perception of Oduduwa The meaning of the name Oduduwa}

According to Samuel Johnson, the word Oduduwa might have originated from the phrase Odu (ti o da iwa). The Yoruba phrase ti o da iwa signified anything that is large in size or big with regard to strength. Johnson (1921:143) specifically used the term $O d u$ to describe either a large-sized container or perhaps a large pot. Johnson's connection of the word Odu with Oduduwa emphasised the strength and the greatness of Oduduwa as the author of existence. Johnson regarded Oduduwa according to the Yoruba oral tradition as the source of creation or a great container. He said the term $\mathrm{Odu}$ '... implies the great container [sic!] the author of existence' (Johnson 1921:143).

Olumide Lucas, a former Pastor of St. Paul's Church in Breadfruit (Lagos), wrote about the Yoruba origins and about

4.Johnson did not state clearly the period at which Oduduwa entered the Yorubaland, but his association of Oduduwa with Christianity or Islam suggests that Odud, but his association of Oduduwa with Christianity or Islam suggests that Oduduwa came to Yorubaland after these two major religions were formed. Afolayan (2004:33) said that Oduduwa might have arrived in Yorubaland sometime around 1100 AD, and Oyebade (2004:53) said sometime around the 7th, 10th o 11 th century $A D$.
Oduduwa as well. ${ }^{5} \mathrm{He}$ wrote extensively on the comparisons between Yoruba religions and those of the ancient Egyptians (Olupona 1993:243). Building on what Johnson had already proposed, Lucas (1948:95) said that the word Oduduwa or Odudua or dua is literally a singular noun that referred to a chief or a very exalted person. He went further to propose that the word Oduduwa could literally be associated with a specific colour. He said that Oduduwa meant 'the Black One' (Lucas 1948:95; Olupona 1993:243). Lucas said that the derivation of the name $d u d u$ meant black and Iwa meant existence; thus, the contraction of Odu ti o da wa, that is, a selfexistent personage whose personality cannot be dissociated from the colour black (Lucas 1948:95).

Lucas believed that the word dua originated from the ancient Egyptian word dua-t, which means 'the other world'. Lucas (1948:95)taught that Odu-dua meant 'Lord of the Other World' or 'Mistress of the Other World'. Dierk Lange questioned Lucas' etymological connection with those of the ancient Egyptians. He said that the phonetic and semantic similarities Lucas proposed between the Egyptian and the Yoruba words are not convincing and should not be used in developing a historical reconstruction regarding the origin of the Yoruba people (Lange 2004:311).

A renowned ethnographer who had great interest in the writing of West African history, Alfred Burdon Ellis (1852-1894), associated the word Odu with colour. Ellis (1966:41) taught that the word $d u$ or $d u d u$ generally meant 'black' and that the association of Oduduwa with the colour black could be because of an ideology among the Yoruba people, according to which black symbolised beauty. It is important to note that the Yoruba people value black skin. Some Yoruba people are proud to associate Oduduwa with black skin (Ellis 1966:41-42).

Following Johnson's proposal on the etymology of the term Oduduwa, 21st century writers of Yoruba history like Afolayan continued to associate the word Oduduwa with the creator of existence. Afolayan (2004), like Johnson and Lucas, for example, said that the name Oduduwa indeed is a resonance that originated from the contraction of the name Odu ti o da iwa and meant that it was Odu [deity or mystery] who created (da) iwa [existence, life and character] (p. 32). Johnson might have been the first person in the 19th century to document the word Oduduwa in connection with the Yoruba origin, and other authors like Lucas Olumide, Ellis and others continued to build upon Johnson's perception of Oduduwa as developed in The History of the Yorubas. Johnson recorded the Oduduwa oral tradition mainly from the elders who informed him about the Yoruba history, many of whom came from Oyo (cf. Johnson 1921:3). However, there are various interpretations that explained the Oduduwa oral tradition among different Yoruba groups.

5.Lucas was born in Lagos on 27 August 1879. He went to St. John's Lagos, CMS Grammar School, Kings College Lagos, London University and Durham University (obtained from 'Addresses and citations in support of honorary graduands at (obtained from 'Addresses and citations in support of honorary graduands at
the Liberty Tadiui, Ibadan on Foundation Day in 1971 by the University of Ibadan', pp. 23-25) 


\section{Oduduwa as a creator}

In all of the Yoruba oral traditions pertaining to the creation of the earth and humans, plants and animals, the image of Oduduwa and that of Obatala (an anthropomorphic sky-god) are portrayed as central. The Yoruba people believed that there would not have been creation without Oduduwa and Obatala (Oyebade 2004:53). The Yoruba creation myth is a tradition according to which God (Olorun) laid down a long chain from heaven until the chain reached the surfaces of the earth. When Olorun laid down the chain, it landed specifically in Ile-Ife, a town in Yorubaland. To be specific, Ile-Ife is in today's Osun state located in the south-western part of Nigeria (Falola \& Heaton 2010). Those who upheld Oduduwa as a creator believed that Ile-Ife is the centre of the universe, and they regarded the entire city as a sacred place because they believed that it was from Ile-Ife that all humans were created and spread to other parts of the world (Ayandele 2004:121; Lange 2004:39).

The Oduduwa creation myth is a view according to which, before the creation of humans, the surface of the earth was filled with mainly bodies of water. When Olorun made Oduduwa to decent from heaven, he gave Oduduwa some items to bring along to earth. The items included a cock, sand or soil and a palm kernel.

Oduduwa spread the soil on the earth's surface that contained mainly water, and the cock helped Oduduwa to spread the soil across the earth, forming a landmass. According to the Yoruba tradition, this single event marked the first landmass on earth. The palm kernel was also thrown to be grown until it was rooted, and it germinated and formed 16 lateral branches. The 16 branches are believed to represent the 16 traditional kingdoms of the Yoruba people (Johnson 1921:4; cf. Ojo 1999:5).

Another view regarding Oduduwa as a creator portrayed that the entire earth was a water-mashed body without any land. Olorun decided to send some of his messengers to earth with the aim of creating farmlands. Those sent included Obatala (Orisa Nla or Orisa Alase), Oduduwa and 16 other immortal beings who were referred to as the 'Oye'. Obatala was tasked with the responsibility of leading all the other Oye. Olorun gave the Oye some items to bring to earth. The items included five pieces of iron given to each Oye, a cockerel and a white piece of cloth. Wrapped inside the white cloth was a lump of soil. Unfortunately, on their way to earth, Obatala got drunk of palm wine, so Oduduwa decided to lead all the other messengers to earth. They all landed in Oke Oramfe at Ile-Ife. The five pieces of iron they came with were set down and the lump of soil spread across the body, providing a landmass. The cockerel spread the soil across the whole earth, leaving some areas filled with water (Akintoye 2004:4; Ayandele 2004:122).
It is not surprising that the Yorubas have high regard for farming and sculpting using iron ores as items and farming as a profession prescribed to them by God himself. The identity of Oduduwa as an independent god is sometimes debated among the Yoruba people. Some Yoruba oral traditions portray Oduduwa as an independent deity who was not created by Olorun, rather a coeval with Olorun (Ellis 1966:41-42). However, in some instances, both Obatala and Oduduwa are regarded as subjects, inferiors or servants of Olorun (Omolewa 2008:58). ${ }^{6}$

\section{Oduduwa as a goddess}

There is another unpopular tradition according to which Oduduwa was created as a blind female and as the wife of Obatala. Ellis explained this Yoruba oral tradition and noted that there was a time when Obatala and Oduduwa were locked up together in darkness by Olorun and kept inside a calabash for many days. Whilst being locked up, both deities became tired and hungry and this resulted in anger, especially for Obatala, who blamed Oduduwa for all their predicaments. Oduduwa also blamed Obatala for causing Olorun to tie both of them in a calabash. Because of his anger, Obatala tore the eyes of Oduduwa and Oduduwa began to see. Instead of being grateful for being able to see, the tradition points that Oduduwa was angry and cursed Obatala for tearing her eyes. Oduduwa cursed Obatala by saying ' $n$ ]aught shalt thou eat but snails' (Ellis 1966:41-42). To this day, the Yoruba people make sacrifices of snails to Obatala. Ellis (1966:41-42) stated that this myth also contributed to making the Yoruba people sacrifice snails to some of their gods.

Ellis mentioned another tradition regarding Oduduwa, according to which Oduduwa, depicted as a female, met a handsome man who was a hunter in a place called Ado (15 miles north of Badagry). Ado literally means a wayward person of either sex. Oduduwa walked the forest and enticed the hunter. It resulted in both having sex for many weeks. Oduduwa became tired and disliked the hunter but promised to protect him in the forest. She also promised protection to all those who passed and worked along Ado (Ellis 1966:43). The discussion about Oduduwa as a female goddess in this research is based on the views of Ellis. Ellis depended on the oral interviews he made with some Yoruba people around the 1880s. Lucas believed that describing Oduduwa as a female deity can be a reasonable

6.Sometimes, the Yoruba creation story is interpreted in this order: that Obatala went to Olurun, a female goddess, to seek permission for the creation of the mountains, to olur, a femains, valleys, forests and the fields. Obatala was granted the permission and he came to the earth with a snail shell full of sand, a white hen, a black cat and a palm nut. Previously, Obatala visited one of the deities in heaven called Orunmila (Prophe God/oldest son of Olorun), who instructed Obatala to obtain a chain from a goldsmith in heaven. Obatala came down with a chain that was not long enough to touch the earth's water surface. Orunmila instructed Obatala to pour out the sand contained in the snail shell; the white hen then spread the sand across the earth. Obatala called the place he landed on as Ife. He planted the palm nuts, which sprouted to a palm tree that produced wine. The black cat kept Obatala company, but he was still bored and decided to make many sculptures (Rosenberg 1999:509-514). Obatala was tired and as a result, he mistakenly started to make deformed sculptures. Olorun decided to protect the deformed sculptures and breathed life into them, and they became human beings. These human beings started the first community on earth in lle-lfe, human beings. These human beings started the first community on earth in lle-lfe, whilst Obatala returned to the sky where he belonged. Olorun was displeased with humans that started a community without her permission. Her anger led her to release a flood that destroyed most part of Obatala's kingdom on earth. The people on earth pleaded with Eshu (the messenger god) to ask Olorun and Obatala for help. Orunmila was sent to earth and he brought the flood to order (Rosenberg 1999:509-514; this information is a summary of the Yoruba creation myth obtained from the book edited by Rosenberg 1999. 
idea because, according to him, Oduduwa was originally a female. Lucas thought that the name Oduduwa was degenerated to a man because her worshippers thought that the role she played in creating the earth should not be attributed to a woman but a man. Lucas (1948) said stories portraying Oduduwa as evil had to be invented so that she would be dissociated from creation:

$[\mathrm{W}]$ ith her adoption as the progenitor of the Yoruba race, there seems to have arisen a tendency to regard her as a leader and a 'hero', in consequence of which late stories transforming her to a male deity were invented. (pp. 93-94)

\section{Oduduwa as a migrant legend}

The Yoruba migration tradition regarding Oduduwa is a view according to which Oduduwa originated from Mecca through his biological father Lamurudu, who was a king in Mecca (Folorunso 2003:87). Oduduwa, then a prince, came to Nigeria together with his two children. The names of the two children are not known or mentioned in any book used for this research, but the parts of Nigeria they went to are mentioned. The two children became the kings of two regions in Northern Nigeria, Gogobiri (Gobir) and Kukuwa (Johnson 1921:4).

In the Yoruba tradition, Oduduwa is portrayed as a popular person in Mecca because he rejected Islam, a religion practised by his ancestors. His interest in paganism was supported by some Muslim adherents whom he convinced to join him and especially a priest called Asara, whose father Braima was a committed Muslim. Asara became an image or idol maker because he hated Islam unlike his father who loved Islam. Braima's father was an idol seller and he introduced the trade to Braima. Johnson (1921) said that when Braima was an idol seller during his childhood, he used to invite buyers by using the euphemism '[ $w]$ ho would purchase falsehood' (p. 4)?

Oduduwa was determined to promote idolatry to the point that he converted one of the mosques in Mecca and made it a shrine for idol worship. Oduduwa ordered his followers to go for 3 days hunting in the bush to prepare them for a ritual that was meant to please their idols. Whilst they were away, Braima went through all of Mecca searching and destroying idols made by Oduduwa and his followers using an axe. ${ }^{7}$ He left the axe on the neck of one of the important idols made by Oduduwa (cf. Johnson 1921:4; Ojo 1999:5). Oduduwa and his followers knew that it was Braima who destroyed their idols. They summoned him for an explanation and Braima said to them ' $[w]$ hy do you worship things which cannot speak' (Johnson 1921:4)? Oduduwa and his followers intended to burn Braima alive and this led to a revolt between Oduduwa and other Muslims in Mecca. The revolt led to the death of Lamurudu, whilst his children including Oduduwa were expelled from Mecca (Johnson 1921:4; cf. Ojo 1999:5).

7.There is another Islamic tradition according to which Abraham, during the PreIslamic period, destroyed idols in Mecca. The subject is beyond the scope of this research.
Oduduwa had to migrate to Yorubaland from Mecca and it is not known why he chose Yorubaland. He left Mecca and went eastwards, taking two of his idols to Ile-Ife. Sahibu, an ardent follower of Islam from Mecca, went after Oduduwa to destroy him and his followers. Sahibu carried with him a copy of the Koran.

Oduduwa defeated Sahibu in a battle (Johnson 1921:4). Johnson said that a copy of the Koran, now referred to as Idi [something tied up], is still available in a temple in Ile-Ife, where it is being venerated unto this day.

Oduduwa arrived at Ile-Ife and met Agbo-niregun (Setilu), the founder of Ifa worship. Johnson said that it took Oduduwa 90 days to travel from Mecca to Ile-Ife (Johnson 1921:4). No one knew the Oni of Ife when Oduduwa went there (Ayandele 2004:123). Johnson narrated the Yoruba oral tradition as a migrant legend, the way he was told by the Yoruba oral historians he came across. However, Johnson contested some aspects of the tradition that concentrated on associating the Yoruba origin with Islam.

\section{Conclusion}

There are various theories of the Yoruba origin which include the Arab, the Jewish, the Etruria, the local and the Egyptian origin of the Yorubas. Many more Yoruba people believe in the Arab origin because the theory is popularly linked to the 'East'. In the original Yoruba oral tradition, their origin is associated with the East and the East had been assumed to be Mecca or Arabia. Johnson disputed the Arab theory of the Yoruba origin because it associated the Yoruba origin or Oduduwa with Islam.

Johnson recognised that a particular legend by the name Oduduwa might have lived in Yorubaland. He might have included Oduduwa in the writing of the Yoruba history because the Yoruba oral tradition ascribed Oduduwa as the original ancestor of the Yoruba people. However, Johnson's emphasis that the Yoruba ancestors came from Upper Egypt or Nubia or that they were Coptic Christians deemphasised the regard for Oduduwa as a single person but a group of people. Johnson did not explain the connection between Oduduwa and the Coptic Christians, instead, he mentioned the identity of Oduduwa as a mythical personage, suggesting that Oduduwa, as a specific individual, might have existed or not. ${ }^{8}$ In addition, the different attributes of Oduduwa as a goddess, a migrant legend and a creator may

8.There is a tradition among the Coptic Egyptians that John Mark came to Egypt around $68 \mathrm{AD}$ to preach the Gospel of Christ and that he founded the Coptic Church (Marcus 2011:4). There was a period that the Coptic Church suffered persecution at the hands of the Romans. For example, the edict of 202 AD banned the Egyptians from converting to Christianity and the edict of $250 \mathrm{AD}$ forced the Egyptians to carry from converting to Christianity and the edict of 250 AD forced the Egyptians to carry with them a certificate indicating that they made sacrifices to the Roman gods. In addition, Emperor Diocletian (284-305) killed many Coptic Christians during his time as Emperor (Marcus 2011:4-5). However, there is no any evidence at present that shows that the persecution of the Coptic Egyptians in the 3rd and 4th centurie led to the migration of the Egyptians to Yorubaland. Sanneh (1983:7-8) said that the persecution of the Coptic Church around $300 \mathrm{AD}$ did not make the Egyptians trave to other countries to preach the Gospel; instead, they used the opportunity to develop more sophisticated liturgical orders in their local churches. 
suggest that the name might have been a title associated with an unknown Yoruba hero or heroine who is an achiever. This is also why the Yorubas of today associate any Yoruba achiever with the title 'Omo Oduduwa' meaning 'descendant of Oduduwa' (Lucas 1948:93). Ayandele (2004:123) also suggested that the purpose of the inclusion of Oduduwa in the Yoruba oral tradition is not to specifically identify the Yoruba origin but to highlight that the Yorubaland prospered during the reign of Oduduwa. It can therefore be speculated that for Johnson, whether the name Oduduwa is included or not in the narrative of the Yoruba origin, he would have been satisfied in associating the ancestors of the Yoruba with Christianity.

His disagreement with a narrative of the Yoruba origin that associated the Yoruba people with Islam might have been influenced by Johnson's socio-religious and political background, according to which he was a clergy that was expected to convert people into Christianity in addition to the role he played in uniting the Yoruba during the periods of the Yoruba war that ended in the late 19th century. Falola (1999) agreed with this view and said 'his [Johnson's] greatest wish was to see the triumph of Christianity over other religions' (p. 46).

\section{Acknowledgements}

The author would like to acknowledge the sponsorship offered by the University of KwaZulu-Natal School of Religion, Philosophy and Classics.

\section{Competing interests}

The author declares that there is no competing interest.

\section{Ethical consideration}

This article followed all ethical standards for a research without direct contact with human or animal subjects.

\section{Author's contributions}

This article was written by A.M.J.

\section{Funding information}

This research received funding from the School of Religion, Philosophy and Classics, University of KwaZulu-Natal.

\section{Data availability statement}

Data sharing is not applicable to this article as no new data were created or analysed in this study.

\section{Disclaimer}

The views expressed in this article are those of the author.

\section{References}

Ade, D.P., 2006, 'Change and continuity: The Yoruba belief in the life after death, lecture held at the Metaxus Institute Philadelphia, 03-07 June, pp. 1-15, viewed 29 April 2013, from http://www.scripd.com/doc59067767/Dopa-Mu.

Afolayan, F., 2004, 'The early Yoruba kingdoms', in N.S. Lawal, M.N.O. Sadiku \& A Dopamu (eds.) Understanding Yoruba life and culture, pp. 31-49, African World Press, Trenton.

Agai, J.M., 2013, 'An investigation into the ancient Egyptian cultural influences on the Yorubas of Nigeria', HTS Teologiese Studies/Theological Studies 69(1), 9. https:// doi.org/10.4102/hts.v69i1.1919

Agai, J.M., 2018, Ethniccracy: Can Africans think beyond ethnicity? Kwarts Publishers, Centurion.

Akintoye, S.A., 2004, 'From early time to the 20th century,' in N.S. Lawal, M.N.O. Sadiku \& A. Dopamu (eds.), Understanding Yoruba life and culture, pp. 3-30, African World Press, Trenton.

Ayandele, E.A., 2004, 'Yorubaland up to 1800', in I. Obaro (ed.), Groundwork of Nigeria history, pp. 121-143, Heinemann Educational Books, Jos.

Awolalu, J.O., 1979, Yoruba Beliefs and Sacrificial Rites, p. xiii, Longman, London.

Doortmont, M.R., 1991, Samuel Johnson (1846-1901): Missionary, Diplomat, and Historian, pp. 167-182, Africa World Press, Trenton.

Ellis, A.B., 1966, The Yoruba-speaking peoples of the slave coast of West Africa, their religion, manners, customs, laws, language, etc., Anthropological Publishers, Oosterhout.

Falola, T., 1999, Yoruba gurus: Indigenous production of knowledge in Africa, African World Press, Trenton.

Falola, T. \& Heaton, M.M., 2010, A history of Nigeria, Cambridge University Press, Cambridge.

Folorunso, C.A., 2003, 'Views of ancient Egypt from a West African Perspective,' in D.O'Connor \& A. Reid (eds.), Ancient Egypt in Africa, pp. 77-94, University College London, London.

Johnson, S., 1921, The history of the Yorubas: From the earliest times to the beginning of the British protectorate, in O. Johnson (ed.), pp. i-613, Abuja, CSS.

Lucas, J.O., 1948, The religion of the Yorubas: Being an account of the religious beliefs and practice of the Yoruba peoples of southern Nigeria, especially in relation to the religion of ancient Egypt, Church Missionary Society, Lagos.

Lucas, J.O., 1970, Religions in West Africa \& ancient Egypt, Lagos.

Marcus, M.A., 2011, History of the Coptic Orthodox Church, pp. 4-18, viewed 10 October 2015, from www.stmary-ottawa.org.

Omolewa, M., 2008, Certificate history of Nigeria, Longman, Ikeja.

Ojo, A., 1999, Yoruba Omo Oduduwa: Papers on Yoruba people, language, and culture, viewed 24 June 2016, from http://www.uga.edu/aflang/YORUBA/ODUDUWA. htm

Olabimtan, K., 2011, 'Hinderer, David 1819 to 1890', in Dictionary of African Christian Biography, African World Press, Trenton, pp. 1-11, viewed 24 June 2016, from https://dacb.org/stories/nigeria/hinderer-david/.

Olabimtan, K.O., 2009, 'Samuel Johnson of Yoruba Land, 1846-1901: Religio-cultural identity in a changing environment and the making of a mission agent', PhD dissertation, School of Religion, Philosophy and Classics, University of Kwa-Zulu Natal.

Olupona, J.K., 1993, 'The study of Yoruba religious tradition in historical perspective,' NUMEN 40(3), 240-273. https://doi.org/10.2307/3270151

Oyebade, O., 2004, 'Reconstructing the past through oral tradition,' in N.S. Lawal, M.N.O. Sadiku \& A. Dopamu, Understanding Yoruba life and culture, pp. 51-61, African World Press, Trenton.

Quadri, Y.A., 1986, 'An appraisal of Muhammad Bello's Infaqul-Mansur Fi TarikhiBildad T- Takrur,' Journal of Arabic and Religious Studies 3(1), 53-62.

Rosenberg, D., 1999, 'The creation of the universe and Ife', in World mythology: An anthology of the great myths and epics, viewed 20 April 2018, from https:// sites google com/a/asu edu/mythology-of-africa/the-creation-of-the-universeand-ife.

Sanneh, L., 1983, West African Christianity: The religious impact, Hurst \& Company, London.

Stevens, S., 2005, The Yorubas and early missionary work among them, viewed 15 October 2015, from http://www.zionchristitanministry.com/international/ africa/the-yorubas-and-early-missionary-work-amongthem/.

Umoh, S.M., 1971, 'Nigeria's multi-ethno-cultural communications system and its influence upon social and business behavior,' PhD dissertation, Dept. of Communications, United State International University.

University of Ibadan, 1971, Addresses and citations in support of honorary graduands at the Liberty Tadiui, Ibadan on Foundation Day in 1971 by the University of at the Liberty Tadiui, Ibadan on Foundation Day in 1971 by the University of source=univ\&tbm=isch\&q=University++of++lbadan,1971,\%E2\%80\%9CAddresses source-univ\&tbm-isch\&q=University+toft+lbadan, $1971, \% E 2 \% 80 \%$ CAddresses +and+citations+in+support+of+honorary+graduands+at+the+Liberty+Tadiui,+lba 9D23-25.\&client=firefox-b-d\&sa=X\&ved=2ahUKEwjoubemg-PqAhVRQhoKHWD AusQ7Al6BAgCEBK\&biw $=1024 \&$ bih $=654$. This program was organised to awar certain dignitaries with honorary doctorate degrees and Olumide Lucas was awarded an honorary degree in Doctor of Letters, honoris causa. 